\title{
The Wife of Bath - Early Feminist?
}

\author{
Vandana Lohia \\ Christ University \\ Bangalore, India \\ vandyberry02@gmail.com
}

The Tale of the Wyf of Bathe - written in $14^{\text {th }}$ century England - remains to be one of the most widely known tales from Geoffrey Chaucer's The Canterbury Tales. Chaucer gives voice to this pilgrim woman at a time when Richard II's England was wrought with imbalance of power in the male dominated society. The purpose of this essay is to discern whether the Wife of Bath was an early feminist or not. She is commonly referred to as "the wife" and not her name - this is precisely the notion that she sets out to defy - that a woman, in a society, can only be identified by relation to a man, be it as a wife, mother, sister or a daughter.

The Wife of Bath - or Alisoun, as she herself tells her name to be - narrates her life's story through the prologue to her tale. At a time when women were expected to be silent unless directly spoken to - Chaucer makes her Prologue almost twice as long as her tale wherein she is able to hold the pilgrims' - composed mostly of men - undivided attention. The General Prologue to her tale states "...married in church, husbands she had five..." The very fact that she married - and remarried, and remarried...- after being widowed, in the eyes of the Church goes on to show her progressive views on marriage and chastity. Robert $\mathrm{M}$. Jordan writes "For her, marriage is not a sacrament (a manifestation of the spiritual) but a 


\section{DOI: https://doi.org/10.24113/ijellh.v8i1.10403}

practical arrangement... Even a husband's funeral provides a matrimonial market day for Alice".

After having outlasted five husbands, she is hopeful to find a sixth one - remaining completely unapologetic. Where the medieval Church viewed remarriage of women as something unimaginable and unforgiving in the eyes of the God, the Wife justifies her position through the Holy Bible itself. She enlists the example of the Samaritan woman that Jesus encounters taken from the Gospel of John which is often thrown as a learning example to her to criticize her unlawful conduct in the ways of marriage by those around her, presumably priests of the Church. She very artfully contradicts this criticism against her by picking out another instance from the Bible, that is, to "Be fruitful and multiply."

"At making clothes she had a skilful hand; she bettered those of Ypres and of Ghent" states the General Prologue about the Wife of Bath. She was so skilled at making clothes that she surpassed the talents of chief seats of the Flemish wool trade, that is, of Ypres and Ghent. Obviously, she was capable of sustaining herself financially by selling her skilfully made clothes. This just goes on to prove that she got married out of choice and not because the society demanded it from her as a woman. Being an elderly widow does not stop her from being on the lookout for a sixth husband and she never compromised on her dressing sense "Her stockings were of the finest scarlet red" - the colour scarlet red being a symbol of her sexual prowess. It is her control over her sexuality that gives her the ability to gain an upper hand in marriage as well - she does not simply submit to the wants and wishes of her husband(s), but voices her opinions and wishes boldly too.

However, Kemp Malone argues that the stance that she vouches for so boldly in her Prologue - that of gaining complete sovereignty over the man to have a happy married life - is 


\section{DOI: https://doi.org/10.24113/ijellh.v8i1.10403}

completely thrown away after she marries her fifth husband. Her life with her Jankin is described by her as follows:

"And whan that I hadde geten unto me, By maistrie, al the soveraynetee,...After that day we hadden never debaat. God helpe me so, I was to hym as kynde As any wyf from Denmark unto Ynde, And also trewe, and so was he to me."

The fact that she goes on to become an obedient and kind wife after marriage stands in sharp contrast with her earlier stance of having 'maistrie' and 'soveraynetee' over her husband. Malone goes on to say the following - "This way of behaving most emphatically does not agree with the Wife of Bath's views on wedded bliss, as set forth in her prologue and repeated in her epilogue. How are we to account for this fundamental difference?"

Although, she does not just simply subscribe to her husband's wishes and let go of her own. It is her fifth husband, Jankin, who hits her so hard that she becomes "somdel deaf". The incident is preceded by the countless number of times that her husband would lounge around, reading aloud from his "book of wikked wyves", thereby inflicting mental torture upon her. When she throws his book in the fire out of frustration, he beats her up. Not being one to simply accept what is done to her; she pretends to be grievously injured and in turn bashes her husband back for injuring her so.

Here, the Wife of Bath brings in the Aesop's fable of the man and the lion - where the man is seen to be taming the lion - whereupon seeing the painting, the lion asks the man how the painting would have looked had it been created by lion instead of a man. The Wife remarks wonderfully "Who painted the lion, tell me who?" The idea behind this proclamation of hers is to explain how the texts in circulation, like, the "book of wikked wyves" and even the Bible are written by men or at least, preached by men and of course, as a result discard the plight of women and their woes in marriage - only looking at everything from a male 
DOI: https://doi.org/10.24113/ijellh.v8i1.10403

perspective, just like the painting of the lion being tamed by the man. She illustrates how if women had the opportunity to express their views, as men do, they too would have brought out the follies and inconsistencies in men as men have been doing for countless of years.

The Wife of Bath does satisfy many ideals and aspects of an early feminist. She challenges the authority of the Church and the Church elders - who propagate dual standards regarding marriage and sexuality for men and women - by giving instances from the Bible itself to provide a defence for her actions and refute the hypocritical doctrines of the Church. Although she does not subscribe to all of the feminist ideals - as she submits to being an obedient wife to her husband - she still advocates for women having equal rights in the institution of marriage and boldly refrains from subscribing to the Church standards of virtuosity and purity and openly accepts her sexuality - just like men of her times.

\section{WORKS CITED}

Jordan, Robert M., James I. Wimsatt, and Mary Carruthers. "The Wife of Bath." Publications of the Modern Language Association of America (1979): 950-953.

(https://www.jstor.org/stable/461979?casa token=Iz66TaX6yMQAAAAA:nW4nh7hyenPdnI $\underline{4 Q G y X V n N f 9 y D f-}$ bnhtW1VHf1zJSX6wCFjxXljorwiXjwUPW6nLGK7EduJdX06Q9xKE7UEuVcsgxjf8j99oR LgN7Q0e7Fw2cob_HWA\&seq=1\#metadata_info_tab_contents) 
DOI: https://doi.org/10.24113/ijellh.v8i1.10403

Longsworth, Robert. "The Wife of Bath and the Samaritan Woman." The Chaucer Review 34.4 (2000): 372-387.

https://www.jstor.org/stable/25096105?casa_token=QYV8nhgr8V4AAAAA:yGW5k4nVg_p LwvAksG9RgVyvhpYIxeJWk7dW_P58InXMafspRnp9VaeUb193jK0z_124CVHVdze5o59 M4TwQycE0KE6hujvRPMWjPiKwO3_DlfOdTTw\&seq=1\#metadata_info_tab_contents Malone, Kemp. "The Wife of Bath's Tale." The Modern Language Review (1962): 481-491. https://www.jstor.org/stable/3720461?casa_token=GOCf1iTbfxYAAAAA:y2mkpWFtfHE0a $\underline{\text { lkbQJn0sisz56yraDd_yYtpZnPFqPNnFq5GihZyq5- }}$ kpNDOW7ZyexJAFZWzsFtMm2U2TuP1-M4Swq9Ta$\underline{\text { rHkKGzABka0iwVZDW9HXI\&seq=1\#metadata_info_tab_contents }}$ 